\title{
Electrospray tandem mass spectrometry of 3'-azido-2',3'dideoxythymidine and of a novel series of 3'-azido-2',3',4'-trideoxy-4'- thio-5-halogenouridines and their respective $\alpha$-anomers
}

\author{
Joseph Banoub ${ }^{1 *}$, Emmanuel Gentil ${ }^{1}$, Bougrine Tber $^{2}$, \\ Nour-Eddine Fahmi ${ }^{2}$, Gino Ronco ${ }^{2}$, Pierre Villa ${ }^{2}$, and Grahame Mackenzie ${ }^{3}$ \\ 1. Northwest Atlantic Fisheries Center, Science Branch, Toxicology Section P.O. Box \\ 5667, St John's Newfoundland, A1C 5X1, Canada, and Department of Biochemistry, \\ Memorial University of Newfoundland, St. John's, Newfoundland, A1B 3X9, Canada, \\ 2. Laboratoire de Chimie Organique et Cinétique, UFR des Sciences, Université de \\ Picardie, 150 rue Saint-Leu, 80000 Amiens, France, 3. School of Chemistry, University \\ of Hull, Cottingham, Road, HULL, HU6 7RX, UK
}

\begin{abstract}
Electrospray mass spectrometry has aided the structural characterization of $3^{\prime}$-azido-2',3'-dideoxythymidine (AZT) and the novel series of $3^{\prime}$-azido-2',3',4'trideoxy-4'-thio-5-(bromo, chloro or fluoro)uridine nucleosides and their respective $\alpha$ anomers. Low energy $\mathrm{CAD} \mathrm{MS} / \mathrm{MS}$ analysis of the protonated molecules $[\mathrm{M}+\mathrm{H}]^{+}$confirmed the predicted fragmentation route for AZT and a series of related 4'-thio-5-halogenouridines. This MS/MS study also provided characteristic fingerprint patterns which permitted differentiation of anomers within the series of 3'-azido2',3',4'-trideoxy-4'-thio-5-halogenouridine nucleosides.
\end{abstract}

\section{Introduction}

The human immunodeficiency virus (HIV) has been accepted as being the etiological agent of acquired immunodeficiency syndrome (AIDS) [1]. Nucleoside analogues such as 3'-azido-2',3'-dideoxythymidine (AZT) [2] and other 2',3'dideoxynucleosides [3] are potent inhibitors of this retrovirus in vitro and in vivo. There is an ongoing search for novel nucleosides which are effective against the AIDS virus.

Systematic structure-reactivity relationship studies of AZT analogues have shown a pronounced enhancement of the anti-HIV activity when the 5-position of the pyrimidine ring is substituted by halogens such as $\mathrm{Br}$ or I [4]. It has also been shown that nucleoside analogues in which the $\mathrm{O}-4^{\prime}$ has been replaced by either a methylene group or sulfur atom are more resistant to nucleoside phosphorylase cleavage $[5,6]$. Also, modifications of this type have conferred such analogues with either or both antiviral and anticancer activities. 
While a large variety of the former types of compounds can now be cited in the literature [7,8], the 4'-thio-analogues are still relatively scarce. As part of a programme aimed at the synthesis of biologically active deoxynucleosides, especially 3'-azido-3'-deoxythymidine, initial attention was directed towards the design of efficient and rapid routes to 3'-azido2',3',4'-trideoxy-4'-thionucleosides, from readily available and inexpensive reagents, in order to generate sufficient amounts for further chemical modifications and biological evaluation. Thus, starting from D-xylose, both 1,5-di-O-acetyl-3-azido-2,3,4-trideoxy-4-thio-ribofuranose and methyl-5-O-acetyl-3-azido-2,3,4-trideoxy-4-thio-D-ribofuranoside were synthesized and converted into 2'-deoxy-5-(bromo, chloro and fluoro)uridines and their respective $\alpha$ anomers. The structural characterization of these novel anomeric pairs of nucleosides has been accomplished [9] using ${ }^{1} \mathrm{H}$ and ${ }^{13} \mathrm{C}$ NMR spectroscopy and elemental analyses.

To our knowledge, there have been no reports on electrospray mass spectrometry of AZT and for the related series of anomeric pairs of novel 3'-azido-2',3',4'-trideoxy-4'thio-5-halogenouridines identified herein.

Fenn and coworkers have shown that electrospray ionization (ES) is a powerful means of producing peptide and protein ions suitable for study by mass spectrometry $[10,11]$. Recently, it has also been shown that the electrospray ionization process is sufficiently mild to detect non-covalent complexes involving a protein and specific ligands [12-14].

This approach has been applied to the study of receptor-drug interactions, proteinprotein interactions [15] and either covalent or noncovalent intermediates formed in enzyme catalyzed reactions [16-18]. Furthermore, electrospray MS has also been used to structurally characterize and differentiate relatively small, single charged amphiphillic regioisomeric esters of sucrose [19]. As a continuation of our interest in the study of carbohydrates by ESMS and ES tandem mass spectrometry, we now report the structural characterization of AZT 1 and the novel series of anomeric pairs of 3'-azido-2',3',4'-trideoxy-4'-thio-5-(bromo, chloro and fluoro)uridines 2-7 (see Figure 1) using ESMS. We also report structural information deduced from the low energy tandem mass spectral analysis of the protonated molecules.

Figure 1. Chemical structures of 3'-azido-2',3'-dideoxythymidine (AZT) 1 and of the novel series of anomeric pairs of 3'-azido-2',3',4'-trideoxy-4'-thio-5-(bromo, chloro and fluoro)uridines 2-7.

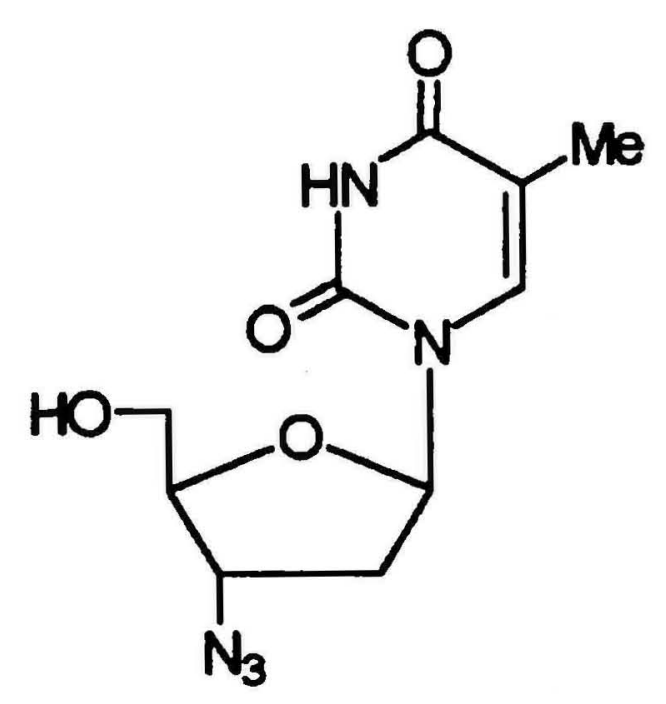

1<smiles></smiles>

2: $\mathrm{X}=\mathrm{Br}$
4:X $=\mathrm{Cl}$
6:X $=\mathrm{F}$<smiles>[X]c1cn(C2CSC(CO)C([N])C2)c(=O)[nH]c1=O</smiles>

3: $\mathrm{X}=\mathrm{Br}$

5: $\mathrm{X}=\mathrm{Cl}$

7: $\mathbf{X}=\mathbf{F}$ 


\section{Experimental}

Compounds and sample preparation:

Synthesis of 3'-azido-2',3',4'-trideoxy-4'-thio-5-(bromo, chloro or fluoro)uridine nucleosides 2-7 were accomplished by a novel method [9]. The purified nucleoside derivatives were dissolved in methanol / water (1/1) containing $0.1 \%$ formic acid . Solutions of $1 \mathrm{mg} / \mathrm{mL}$ of derivatives were prepared prior to mass spectral analysis.

Mass Spectrometry:

Conventional mass spectra were obtained by scanning the mass spectrometer from 50 to $1000 \mathrm{Da}$ in $10 \mathrm{~s}$. Assisted nebulized electrospray mass spectra were obtained using an API III triple quadrupole mass spectrometer (SCIEX, Thornhill, Ontario, Canada) equipped with an atmospheric pressure ionization (API) source operated in the ion spray mode (also known as assisted nebulized electrospray). For the sake of convenience, in this rationale, no distinction was made between the terms ion spray and electrospray which, nowadays, normally includes the assisted nebulizer notion. A Macintosh IIX computer was used for data acquisition and data processing. Samples were introduced to the mass spectrometer by infusing a solution at a flow rate of $5 \mu \mathrm{L} / \mathrm{min}$. The voltage of the ion spray needle was maintained at $5 \mathrm{kV}$, while the orifice voltage was typically $100 \mathrm{~V}$. A $0,6 \mathrm{~L} / \mathrm{min}$ flow of high purity air was used as the nebulizing gas.

Tandem mass spectrometry experiments were also done using the API III instrument. Fragment ion spectra of mass-selected ions were induced by collisions with argon in the second (RF only) quadrupole. The resulting fragments were mass analyzed by the third quadrupole. The target thickness was typically $3 \times 10^{14}$ atoms $/ \mathrm{cm}^{2}$ and collision energies of approximately $100 \mathrm{eV}$ (laboratory frame) were used in all MS/MS experiments. Precursor ion scans were obtained by scanning the first quadrupole while selecting a given $\mathrm{m} / \mathrm{z}$ value with the third quadrupole.

\section{Results and discussion}

The electrospray MS of 3'-azido-2',3'-dideoxythymidine 1 is shown in Figure 2a and summarized in Table 1 . The spectrum showed abundant protonated molecules $[\mathrm{M}+\mathrm{H}]^{+}$at $\mathrm{m} / \mathrm{z} 268$ as well as high intensities of dimer and trimer clusters corresponding to $[2 \mathrm{M}+\mathrm{H}]^{+}$ and $[3 \mathrm{M}+\mathrm{H}]^{+}$at $\mathrm{m} / \mathrm{z} 535$ and 802 respectively. These peaks permitted the confirmation of the relative mass of AZT. Contrary to the FAB MS of nucleosides [20,21], thus far investigated,no characteristic fragment ions were detected which were derived from either the protonated molecules or clusters.

Table 1

Positive electrospray mass spectrum of 3'-azido-3'-deoxythymidine $1\left(\mathrm{C}_{10} \mathrm{H}_{13} \mathrm{~N}_{5} \mathrm{O}_{4}, \mathrm{M} . \mathrm{Wt}=267.1\right)$

\begin{tabular}{lll}
\hline Characteristic ion & $\mathrm{m} / \mathrm{z}$ & $\%$ \\
& 802 & 72.3 \\
{$\left[3 \mathrm{M}+\mathrm{H}^{+}\right.$} & 535 & 100 \\
{$\left[2 \mathrm{M}+\mathrm{H}^{+}\right.$} & 268 & 84.8 \\
{$[\mathrm{M}+\mathrm{H}]^{+}$} & & \\
\hline
\end{tabular}


a

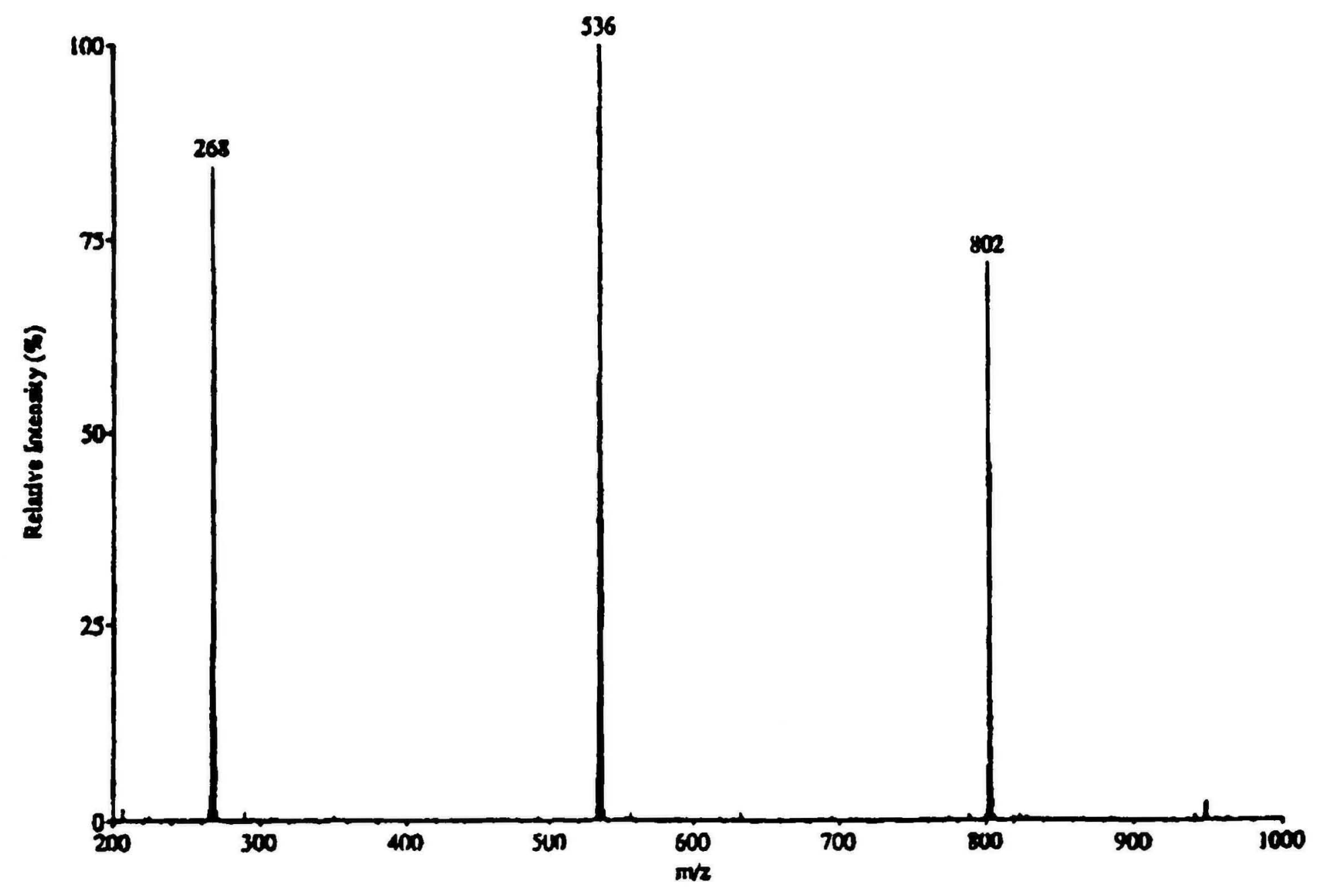

i

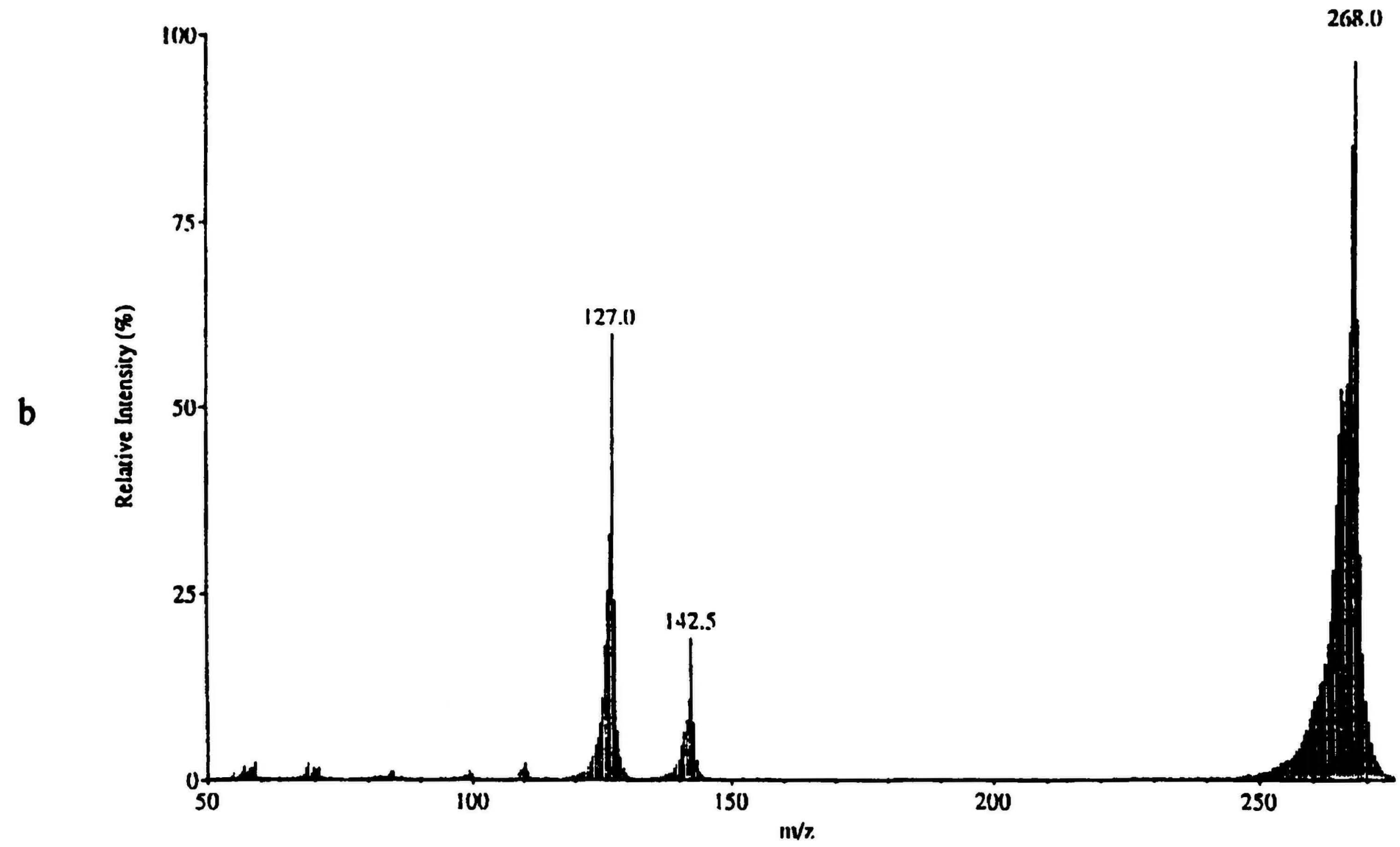

Figure 2. a) Positive electrospray mass spectrum of 3'-azido-3'-deoxythymidine 1. b) Low energy CAD MS/MS spectrum of the precursor ion $[\mathrm{M}+\mathrm{H}]^{+}$at $\mathrm{m} / \mathrm{z} 268$ obtained from 3'-azido-3'-deoxythymidine 1. 
Structural information, such as the sequence pattern of branched oligosaccharides [22-25] or differentiation of isomeric hexosyl units [26-33], can be obtained by tandem mass spectrometry $[34,35]$. The unique dissociation patterns of the precursor ions provide characteristic fragment-ions which facilitate differentiation of isomeric species. Application of high energy collision-induced dissociations (CID) has also proven to be of use in the structural characterization of native polysaccharide antigens [36], isomers of peracetylated saccharides [26-32], anomeric pairs and regioisomers of nucleosides [37-39], C-glycosides [40-43], series of diastereomeric 1,2-trans-2-deoxy-2-iodoglycosyl azides [44] and phosphoramidates [45]. Low energy collision induced dissociations (CID) have also been demonstrated by electrospray ionization for a series of distinct regioisomeric esters of sucrose [19]. Thus, low energy tandem mass spectrometric analysis was conducted on protonated AZT 1 molecules $[\mathrm{M}+\mathrm{H}]^{+}$to explore the possible electrospray fragmentation and compare them with the various fragment-ions obtained by both conventional fast-atom bombardment (FAB) mass spectrometry and FAB MS/MS observed for other nucleosides [20]. A product ion spectrum, arising from fragmentation in the $\mathrm{RF}$ only middle quadrupole collision cell of the triple quadrupole instrument, was obtained.

The low energy CID MS/MS spectrum for the $[\mathrm{M}+\mathrm{H}]^{+}$precursor ion at $\mathrm{m} / \mathrm{z} 268$ is shown in Figure $2 \mathrm{~b}$ and summarized in Table 2. The fragmentation route for the $[\mathrm{M}+\mathrm{H}]^{+}$ parent-ion has been rationalized using the systematic nomenclature for nucleoside fragmentation in FAB-MS proposed by Crow et al [20]. Therefore, the main fragment-ion $\left[\mathrm{BH}_{2}\right]^{+}$at $\mathrm{m} / \mathrm{z} 127$ appears to be initiated by intramolecular transfer of a hydrogen atom from the sugar to the base, which is already protonated (Fig. 2b). The only other ion produced was the less abundant fragment-ion $[\mathrm{S}]^{+}$at $\mathrm{m} / \mathrm{z} 142$ obtained by cleavage of the glycosidic bond with charge retention on the sugar moiety (A-type cleavage) [20].

Table 2

Low energy CAD MS/MS spectrum of the precursor ion $[\mathrm{M}+\mathrm{H}]^{+}$at $\mathrm{m} / \mathrm{z} 268$ obtained for AZT 1.

$\begin{array}{llll}\text { Characteristic ion } & \text { Type of ion } & \mathrm{m} / \mathrm{z} & \% \\ {[\mathrm{M}+\mathrm{H}]^{+}} & \text {precursor ion } & 268 & 100 \\ {[\mathrm{M}+\mathrm{H}-126]^{+}} & \text {3-azido-glycosyl or }[\mathrm{S}]^{+} & 142 & 18.8 \\ {[\mathrm{M}+\mathrm{H}-142+\mathrm{H}]^{+}} & \text {diprotonated base or }\left[\mathrm{BH}_{2}\right]^{+} & 127 & 60.0\end{array}$

The electrospray mass spectra of the pair, 3'-azido-2',3',4'-trideoxy-4'-thio-5bromouridine 2 and its $\alpha$-anomer 3 are summarized in Table 3. It can be seen that ESMS for this anomeric pair are very similar. As expected, each of the anomers of 4'-thio-5bromouridines 2 and 3 formed the protonated molecules $[\mathrm{M}+\mathrm{H}]^{+}$at $\mathrm{m} / \mathrm{z} 350$ and 348 respectively in almost equal ratio and is in accordance with the isotopic abundance of bromine (ie. ${ }^{79} \mathrm{Br}$ and ${ }^{81} \mathrm{Br}$ ). An interesting finding was the presence of clusters of $[2 \mathrm{M}+\mathrm{H}]^{+}$ at $\mathrm{m} / \mathrm{z} 699$ and 695 corresponding to $\left[2\left(\mathrm{C}_{9} \mathrm{H}_{10} \mathrm{~N}_{5} \mathrm{O}_{3} \mathrm{~S}^{81} \mathrm{Br}\right)+\mathrm{H}\right]^{+}$and $\left[2\left(\mathrm{C}_{9} \mathrm{H}_{10} \mathrm{~N}_{5} \mathrm{O}_{3} \mathrm{~S}^{79} \mathrm{Br}\right)+\mathrm{H}\right]^{+}$, respectively. Equally noteworthy was the presence of an intense mixed cluster of $[2 \mathrm{M}+\mathrm{H}]^{+}$ formed by combination of the two bromine isotopes $\left[\mathrm{C}_{9} \mathrm{H}_{10} \mathrm{~N}_{5} \mathrm{O}_{3} \mathrm{~S}^{81} \mathrm{Br}+\mathrm{C}_{9} \mathrm{H}_{10} \mathrm{~N}_{5} \mathrm{O}_{3} \mathrm{~S}^{79} \mathrm{Br}+\right.$ $\mathrm{H}]^{+}$at $\mathrm{m} / \mathrm{z} 697$. The presence of these peaks permitted the determination of the relative 
masses of this anomeric pair. It should be mentioned that some fragmentation of the protonated molecules and clusters occurred during the conventional ESMS and the same characteristic fragmentations, due to the loss of bromine atoms, were observed.

The protonated molecules $\left[\mathrm{C}_{9} \mathrm{H}_{10} \mathrm{~N}_{5} \mathrm{O}_{3} \mathrm{~S}^{79} \mathrm{Br}+\mathrm{H}\right]^{+}$at $\mathrm{m} / \mathrm{z} 348$ were selected for the recording of the low-energy collision induced (CID) mass analyzed ion kinetic energy (MIKE) spectra in order to probe further the electrospray fragmentation behaviour and also to see whether it would be possible to obtain discriminating differences, between the two related anomers 2 and 3, by the metastable analysis . The low energy CID MS/MS of the precursor $[\mathrm{M}+\mathrm{H}]^{+}$ions at $\mathrm{m} / \mathrm{z} 348$ are summarized in Table 4 and tentatively depicted in figure 3. Examination of Table 4 permitted us to deduce the fate of the parent ions and their dissociations into product ions. Interestingly, the product ions obtained, which are of diagnostic importance for the elucidation of this anomeric pair, were not formed in the conventional electrospray MS. As expected, the diagnostic product ions result from the sugar moiety $[\mathrm{S}]^{+}$product ion at $\mathrm{m} / \mathrm{z} 158$. We noted three ions originating from the product ion $[\mathrm{S}]^{+}$at $\mathrm{m} / \mathrm{z} 115,97$ and 85 , which were obtained by elimination of a molecule of hydrogen azide to from the $\left[\mathrm{S}-\mathrm{HN}_{3}\right]^{+}$ion at $\mathrm{m} / \mathrm{z} 115$, by consecutive losses of molecules of hydrogen azide and water to form the $\left[\mathrm{S}-\mathrm{HN}_{3}-\mathrm{H}_{2} \mathrm{O}\right]^{+}$ion at $\mathrm{m} / \mathrm{z} 97$ and by consecutive elimination of molecules of hydrogen azide and formaldehyde to form the $\left[\mathrm{S}-\mathrm{HN}_{3}-\mathrm{HCHO}\right]^{+}$ ion at $\mathrm{m} / \mathrm{z} 85$. These last three product ions seem only to be present for all the members of the 4'-thio-5-halogenouridine nucleoside series and are absent in the case of AZT 1.

Table 3

Positive electrospray mass spectra of 3'-azido-2',3',4'-trideoxy-4'-thio-5-bromouridine 2 and its corresponding $\alpha$-anomer $3\left(\mathrm{C}_{9} \mathrm{H}_{10} \mathrm{~N}_{5} \mathrm{O}_{3} \mathrm{~S}^{79} \mathrm{Br}\right.$, M.W.t $\left.=347 ; \mathrm{C}_{9} \mathrm{H}_{10} \mathrm{~N}_{5} \mathrm{O}_{3} \mathrm{~S}^{81} \mathrm{Br}, \mathrm{M} . \mathrm{Wt}=349\right)$.

\begin{tabular}{|c|c|c|c|c|}
\hline Characteristic ion & Type of ion & $\mathrm{m} / \mathbf{z}$ & $\begin{array}{c}\beta \text {-anomer } \\
(\%)\end{array}$ & $\begin{array}{c}\alpha \text {-anomer } \\
(\%)\end{array}$ \\
\hline \multirow[t]{3}{*}[2\mathrm{M}+\mathrm{H}]{$^{+}$} & {$\left[2\left(\mathrm{C}_{9} \mathrm{H}_{10} \mathrm{~N}_{5} \mathrm{O}_{3} \mathrm{~S}^{81} \mathrm{Br}+\mathrm{H}\right]^{+}\right.$} & 699 & 31.7 & 33.9 \\
\hline & {$\left[\mathrm{C}_{9} \mathrm{H}_{10} \mathrm{~N}_{5} \mathrm{O}_{3} \mathrm{~S}^{81} \mathrm{Br}+\mathrm{C}_{9} \mathrm{H}_{10} \mathrm{~N}_{5} \mathrm{O}_{3} \mathrm{~S}^{79} \mathrm{Br}+\mathrm{H}\right]^{+}$} & 697 & 50.7 & 56.2 \\
\hline & {$\left[2\left(\mathrm{C}_{9} \mathrm{H}_{10} \mathrm{~N}_{5} \mathrm{O}_{3} \mathrm{~S}^{79} \mathrm{Br}+\mathrm{H}\right]^{+}\right.$} & 695 & 26.9 & 31.2 \\
\hline \multirow{2}{*}[2\mathrm{M}+\mathrm{H}-\mathrm{Br}]{$^{+}$} & {$[699-81]+,[697-79]^{+}$} & 618 & 10.8 & 15.0 \\
\hline & {$[697-81]+,[695-79]^{+}$} & 616 & 9.1 & 10.1 \\
\hline \multirow{2}{*}[\mathrm{M}+\mathrm{NH}_{4}]{$^{+}$} & {$\left[\mathrm{C}_{9} \mathrm{H}_{10} \mathrm{~N}_{5} \mathrm{O}_{3} \mathrm{~S}^{81} \mathrm{Br}+\mathrm{NH}_{4}\right]^{+}$} & 367 & 12.5 & 7.1 \\
\hline & {$\left[\mathrm{C}_{9} \mathrm{H}_{10} \mathrm{~N}_{5} \mathrm{O}_{3} \mathrm{~S}^{7} \mathrm{Br}+\mathrm{NH}_{4}\right]^{+}$} & 365 & 7.5 & 6.3 \\
\hline \multirow{2}{*}[\mathrm{M}+\mathrm{H}]{$^{+}$} & {$\left[\mathrm{C}_{9} \mathrm{H}_{10} \mathrm{~N}_{5} \mathrm{O}_{3} \mathrm{~S}^{81} \mathrm{Br}+\mathrm{H}\right]^{+}$} & 350 & 100 & 100 \\
\hline & {$\left[\mathrm{C}_{9} \mathrm{H}_{10} \mathrm{~N}_{5} \mathrm{O}_{3} \mathrm{~S}^{79} \mathrm{Br}+\mathrm{H}\right]^{+}$} & 348 & 96.8 & 93.0 \\
\hline$[\mathrm{M}+\mathrm{H}-\mathrm{Br}]^{+}$ & & 269 & 28.2 & 27.0 \\
\hline
\end{tabular}




\section{Table 4}

Low energy CAD MS/MS spectra of the precursor ions $[\mathrm{M}+\mathrm{H}]^{+}$at $\mathrm{m} / \mathrm{z} 348$ of 3'-azido-2',3',4'-trideoxy-4'thio-5-bromouridine 2 and its corresponding $\alpha$-anomer 3.

\begin{tabular}{lllcc} 
Characteristic ion & Type of ion & $\mathrm{m} / \mathrm{z}$ & $\begin{array}{c}\beta \text {-anomer } \\
(\%)\end{array}$ & $\begin{array}{c}\alpha \text {-anomer } \\
(\%)\end{array}$ \\
& & & 91.2 & 98.2 \\
{$[\mathrm{M}+\mathrm{H}]^{+}$} & Precursor ion & 348 & 100 & 100 \\
{$\left[\mathrm{M}+\mathrm{H}-158+\mathrm{H}^{+}\right.$} & {$\left[\mathrm{BH}_{2}\right]^{+}$} & 191 & 10.8 & 9.8 \\
{$[\mathrm{M}+\mathrm{H}-158+\mathrm{H}-18]^{+}$} & {$\left[\mathrm{BH}_{2}-\mathrm{H}_{2} \mathrm{O}\right]^{+}$} & 173 & 50.9 & 60.3 \\
{$[\mathrm{M}+\mathrm{H}-190]^{+}$} & {$[\mathrm{S}]^{+}$} & 158 & 9.8 & 12.5 \\
{$[\mathrm{M}+\mathrm{H}-190-43]^{+}$} & {$\left[\mathrm{S}-\mathrm{HN}_{3}\right]^{+}$} & 115 & 11.6 & 13.4 \\
{$[\mathrm{M}+\mathrm{H}-190-43-18]^{+}$} & {$\left[\mathrm{S}-\mathrm{HN}_{3}-\mathrm{H}_{2} \mathrm{O}\right]^{+}$} & 97 & 31.3 & 38.8 \\
{$[\mathrm{M}+\mathrm{H}-190-43-30]^{+}$} & {$\left[\mathrm{S}-\mathrm{HN}_{3}-\mathrm{HCHO}^{+}\right.$} & 85 & & \\
\hline
\end{tabular}

\section{Table 5}

Positive electrospray mass spectra of 3'-azido-2',3',4'-trideoxy-4'-thio-5-chlorouridine 4 and its corresponding $\alpha$-anomer $5\left(\mathrm{C}_{9} \mathrm{H}_{10} \mathrm{~N}_{5} \mathrm{O}_{3} \mathrm{~S}^{35} \mathrm{Br}\right.$, M.W.t $=303 ; \mathrm{C}_{9} \mathrm{H}_{10} \mathrm{~N}_{5} \mathrm{O}_{3} \mathrm{~S}^{37} \mathrm{Br}$, $\mathrm{M} . \mathrm{Wt}=305)$.

\begin{tabular}{|c|c|c|c|c|}
\hline $\begin{array}{c}\text { Characteristic } \\
\text { ion }\end{array}$ & $\begin{array}{l}\text { Type } \\
\text { of ion }\end{array}$ & $\mathrm{m} / \mathrm{z}$ & $\begin{array}{c}\beta \text {-anomer } \\
(\%)\end{array}$ & $\begin{array}{c}\alpha \text {-anomer } \\
\text { (\%) }\end{array}$ \\
\hline & {$\left[2\left(\mathrm{C}_{9} \mathrm{H}_{10} \mathrm{~N}_{5} \mathrm{O}_{3} \mathrm{~S}^{35} \mathrm{Cl}\right)+\mathrm{C}_{9} \mathrm{H}_{10} \mathrm{~N}_{5} \mathrm{O}_{3} \mathrm{~S}^{37} \mathrm{Cl}+\mathrm{H}^{+}\right.$} & 912 & - & 10.7 \\
\hline \multirow[t]{2}{*}[3\mathrm{M}+\mathrm{H}]{$^{+}$} & $52\left(\mathrm{CH} N O \mathrm{C}^{35} \mathrm{Cl}\right)+\mathrm{Ln}^{+}$ & 010 & & 00 \\
\hline & 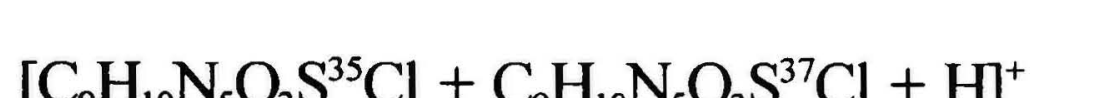 & 600 & - & 173 \\
\hline \multirow[t]{2}{*}[2\mathrm{M}+\mathrm{H}]{$^{+}$} & 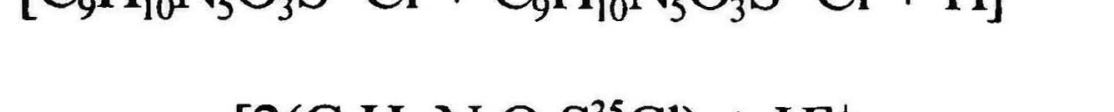 & & & \\
\hline & {$\left[2\left(\mathrm{C}_{9} \mathrm{H}_{10} \mathrm{~N}_{5} \mathrm{O}_{3} \mathrm{~S}^{35} \mathrm{Cl}\right)+\mathrm{H}\right]^{+}$} & 607 & - & 58.0 \\
\hline \multirow{2}{*}[\mathrm{M}+\mathrm{NH}_{4}]{$^{+}$} & {$\left[\mathrm{C}_{9} \mathrm{H}_{10} \mathrm{~N}_{5} \mathrm{O}_{3} \mathrm{~S}^{37} \mathrm{Cl}+\mathrm{NH}_{4}\right]^{+}$} & 323 & 18.7 & - \\
\hline & {$\left[\mathrm{C}_{9} \mathrm{H}_{10} \mathrm{~N}_{5} \mathrm{O}_{3} \mathrm{~S}^{35} \mathrm{Cl}+\mathrm{NH}_{4}\right]^{+}$} & 321 & 100 & - \\
\hline \multirow{2}{*}[\mathrm{M}+\mathrm{H}]{$^{+}$} & {$\left[\mathrm{C}_{9} \mathrm{H}_{10} \mathrm{~N}_{5} \mathrm{O}_{3} \mathrm{~S}^{37} \mathrm{Cl}+\mathrm{H}\right]^{+}$} & 306 & 13.8 & 45.1 \\
\hline & {$\left[\mathrm{C}_{9} \mathrm{H}_{10} \mathrm{~N}_{5} \mathrm{O}_{3} \mathrm{~S}^{35} \mathrm{Cl}+\mathrm{H}^{+}\right.$} & 304 & 34.4 & 100 \\
\hline
\end{tabular}




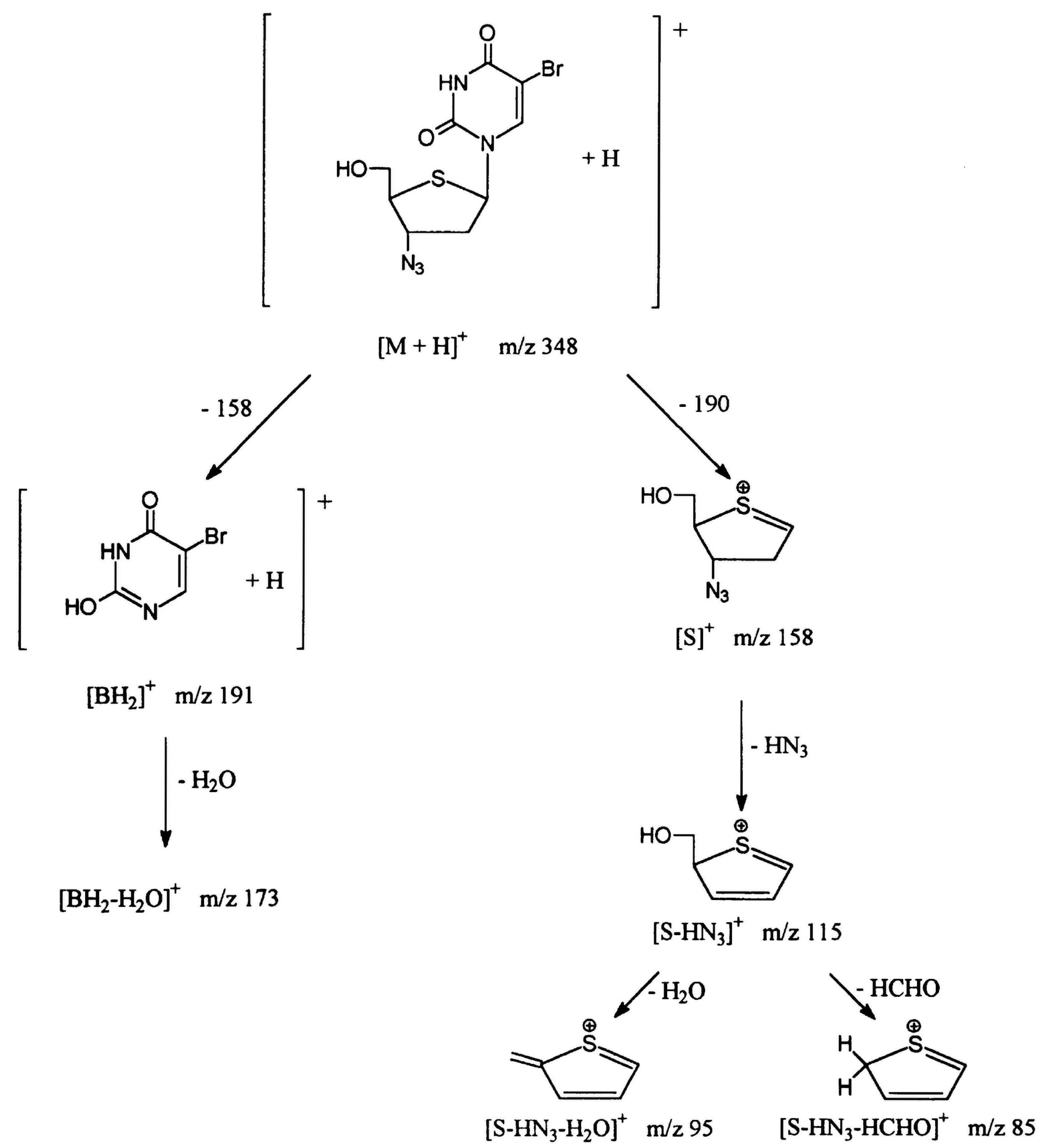

Figure 3. Proposed major fragmentation routes of the $[\mathrm{M}+\mathrm{H}]^{+}$ion observed by $\mathrm{CAD} \mathrm{MS} / \mathrm{MS}$ of the $3^{\prime}-$ azido-2',3',4'-trideoxy-4'-thio-5-bromouridine 2. 

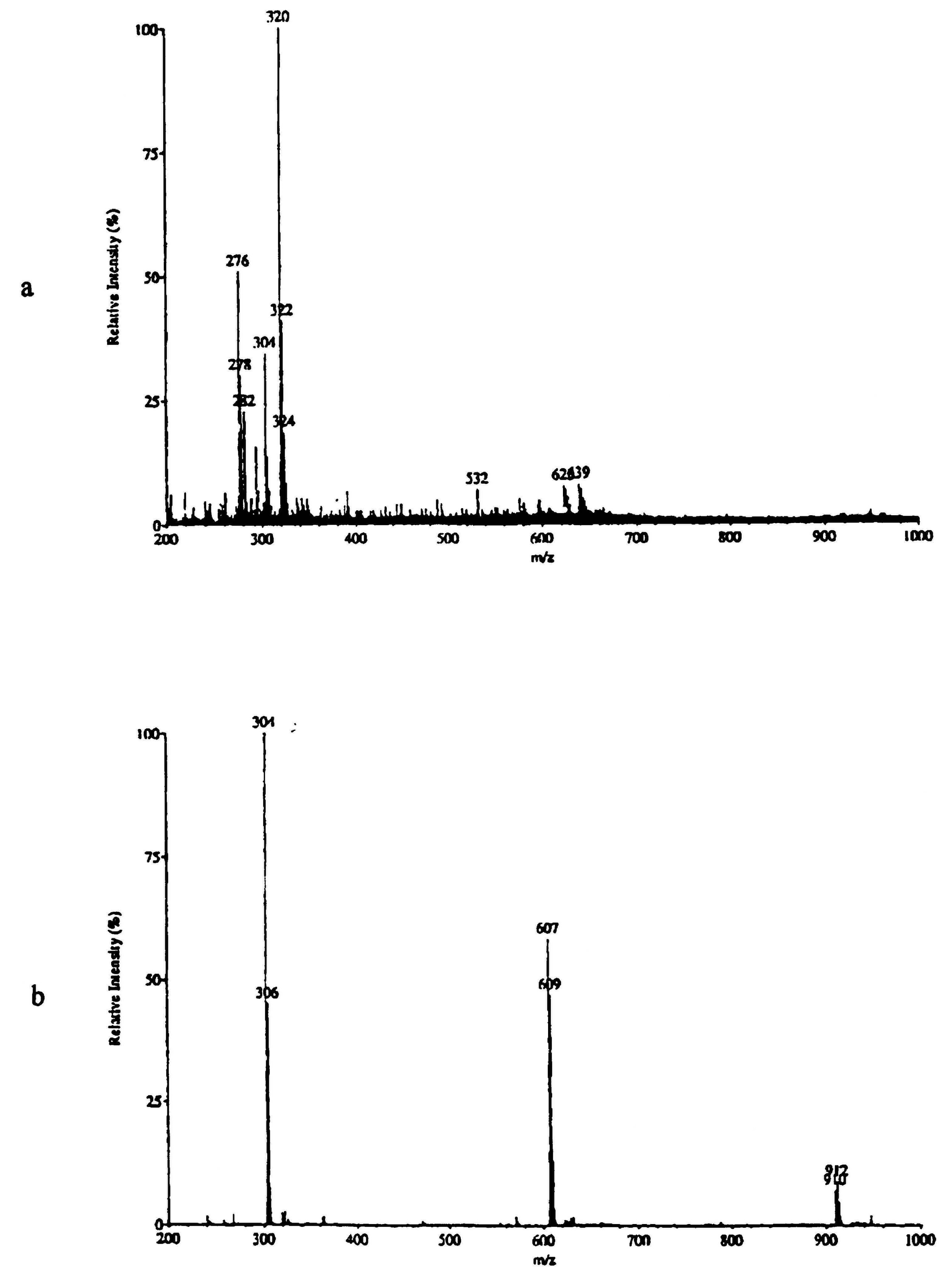

Figure 4. Positive electrospray mass spectra of (a) 3'-azido-2',3',4'-trideoxy-4'-thio-5-chlorouridine 4 and (b) its corresponding $\alpha$-anomer 5 . 
Comparison between the low energy CID MS/MS analyses for this anomeric pair 2 and 3 (Table 4) showed small differences in the intensities of almost all product ions with the exception of the $[\mathrm{S}]^{+}$and $\left[\mathrm{S}-\mathrm{HN}_{3}-\mathrm{HCHO}\right]^{+}$product ions at $\mathrm{m} / \mathrm{z} 158$ and 85 respectively which showed pronounced differences in their relative intensities. These MS/MS characteristics allowed discrimination to be made between the two related anomers 2 and 3.

In a similar fashion, 3'-azido-2',3',4'-trideoxy-4'-thio-5-chlorouridine 4 and its respective $\alpha$-anomer 5 were also studied by electrospray. The characteristic ions obtained for this pair of anomers are presented in Table 5 and Figure 4. Comparison of these data shows very distinct spectral differences between the two anomers. Indeed, the only common ions for this anomeric pair are the protonated molecules $[\mathrm{M}+\mathrm{H}]^{+}$at $\mathrm{m} / \mathrm{z} 306$ and 304 with different relative abundances (each anomer with the correct abundances for the isotopes of chlorine atoms). The exclusive presence of the diagnostic ammoniated adducts $\left[\mathrm{C}_{9} \mathrm{H}_{10} \mathrm{~N}_{5} \mathrm{O}_{3} \mathrm{~S}^{37} \mathrm{Cl}+\mathrm{NH}_{4}\right]^{+}$and $\left[\mathrm{C}_{9} \mathrm{H}_{10} \mathrm{~N}_{5} \mathrm{O}_{3} \mathrm{~S}^{35} \mathrm{Cl}+\mathrm{NH}_{4}\right]^{+}$can be seen, for the $\beta$-anomer only, at $\mathrm{m} / \mathrm{z} 323$ and 321 respectively. While the presence of these adducts, in the case of the $\beta$-anomer 4, can be tentatively rationalized by the formation of a complex involving the ammonium ion held by H-bonding between 4'-S- and 5'-O- atoms of the sugar moiety and 2-carbonyl oxygen atom of the pyrimidine base, such a complex could not be formed in the case of the $\alpha$-anomer 5. However, for this anomer the exclusive formation of $[3 \mathrm{M}+\mathrm{H}]^{+}$ cluster ions can be observed, resulting from the different permutation of the two isotopes of chlorine atoms to yield respectively: either the cluster ion $\left[2\left(\mathrm{C}_{9} \mathrm{H}_{10} \mathrm{~N}_{5} \mathrm{O}_{3} \mathrm{~S}^{35} \mathrm{Cl}\right)\right.$ $\left.+\mathrm{C}_{9} \mathrm{H}_{10} \mathrm{~N}_{5} \mathrm{O}_{3} \mathrm{~S}^{37} \mathrm{Cl}+\mathrm{H}\right]^{+}$at $\mathrm{m} / \mathrm{z} 912$ containing two ${ }^{35} \mathrm{Cl}$ and one ${ }^{37} \mathrm{Cl}$ atoms or the related cluster ion $\left[3\left(\mathrm{C}_{9} \mathrm{H}_{10} \mathrm{~N}_{5} \mathrm{O}_{3} \mathrm{~S}^{35} \mathrm{Cl}\right)+\mathrm{H}\right]+$ at $\mathrm{m} / \mathrm{z} 910$ containing three ${ }^{35} \mathrm{Cl}$ atoms . Similarly, the formation of the $[2 \mathrm{M}+\mathrm{H}]^{+}$cluster ions at $\mathrm{m} / \mathrm{z} 609$ and 607 are formed exclusively for the $\alpha$-anomer 5.

In order to further establish the structural elucidation of this pair of anomeric nucleosides 4 and 5 , the protonated molecules $\left[\mathrm{C}_{9} \mathrm{H}_{10} \mathrm{~N}_{5} \mathrm{O}_{3} \mathrm{~S}^{35} \mathrm{Cl}+\mathrm{H}\right]^{+}$at $\mathrm{m} / \mathrm{z} 304$ were selected for recording by metastable MS/MS analysis. The low energy CAD MS/MS analysis of the precursor ions at $\mathrm{m} / \mathrm{z} 304$ are presented in Table 6 and Figure 5 . Comparison between these two sets of data is in agreement with a fragmentation route typical of that which is expected for such kinds of 4'-thio-nucleosides. Thus, for both anomers, we observed the typical $[\mathrm{S}]^{+}$and $\left[\mathrm{BH}_{2}\right]^{+}$product ions, respectively, at $\mathrm{m} / \mathrm{z} 158$ and 147. As in the case of the anomeric pair 2 and 3 , identification can be made of the three fragment-ions at $\mathrm{m} / \mathrm{z} 115,97$ and 85 , originating from the sugar moiety product ions $[\mathrm{S}]^{+}$, respectively obtained by either the loss of a molecule of hydrogen azide or "consecutive and perhaps concerted losses" of either both molecules of hydrogen azide and water or both molecules of hydrogen azide and formaldehyde. In this context, please note that "consecutive or concerted losses" of many of such product ions, in MS/MS experiments, simply means that they are both lost at the same time and within the same reaction region inside the tandem mass spectrometer. It is difficult to deduce the order of elimination reaction involving "consecutive or concerted losses" under the condition of MS/MS.

Examination of Table 6 permits the identification of pronounced and discriminating characteristic differences to be made between the relative abundances of the common product ions $[\mathrm{S}]^{+},\left[\mathrm{BH}_{2}\right]^{+},\left[\mathrm{S}-\mathrm{HN}_{3}\right]^{+}$and $\left[\mathrm{S}-\mathrm{HN}_{3}-\mathrm{H}_{2} \mathrm{O}\right]^{+}$respectively at $\mathrm{m} / \mathrm{z} 158,147,115$ and 97. Such distinct differences makes possible the clear differentiation of the pair of anomeric nucleosides 4 and 5. The low energy CID MS/MS analysis of the chlorine-37 isotope of the ammoniated adduct $\left[\mathrm{M}+\mathrm{NH}_{4}\right]^{+}$at $\mathrm{m} / \mathrm{z} 321$ of the $3^{\prime}$-azido-2',3',4'-trideoxy-4'thio-5-chlorouridine $\beta$-anomer was also recorded and is presented in Table 7. In addition, Table 7 identifies the same type of product ions observed for the collision induced decomposition of the protonated molecules of $[\mathrm{M}+\mathrm{H}]^{+}$precursor ions presented in Table 6. 


\section{Table 6}

Low energy CAD MS/MS spectra of the precursor ions $[\mathrm{M}+\mathrm{H}]^{+}$at $\mathrm{m} / \mathrm{z} 304$ of 3'-azido-2',3',4'-trideoxy-4'thio-5-chlorouridine 4 and its corresponding $\alpha$-anomer 5 .

\begin{tabular}{|c|c|c|c|c|}
\hline Characteristic ion & Type of ion & $\mathrm{m} / \mathrm{z}$ & $\begin{array}{c}\beta \text {-anomer } \\
(\%)\end{array}$ & $\begin{array}{c}\alpha \text {-anomer } \\
(\%)\end{array}$ \\
\hline $\begin{array}{l}{\left[\mathrm{M}+\mathrm{H}^{+}\right.} \\
{[\mathrm{M}+\mathrm{H}-146]^{+}} \\
{[\mathrm{M}+\mathrm{H}-158+\mathrm{H}]^{+}} \\
{[\mathrm{M}+\mathrm{H}-146-43]^{+}} \\
{[\mathrm{M}+\mathrm{H}-146-43-18]^{+}} \\
{[\mathrm{M}+\mathrm{H}-146-43-30]^{+}}\end{array}$ & $\begin{array}{c}\text { Precursor ion } \\
{[\mathrm{S}]^{+}} \\
{\left[\mathrm{BH}_{2}\right]^{+}} \\
{\left[\mathrm{S}-\mathrm{NH}_{3}\right]^{+}} \\
{\left[\mathrm{S}-\mathrm{HN}_{3}-\mathrm{H}_{2} \mathrm{O}\right]^{+}} \\
{\left[\mathrm{S}-\mathrm{HN}_{3}-\mathrm{HCHO}^{+}\right.}\end{array}$ & $\begin{array}{l}304 \\
158 \\
147 \\
115 \\
97 \\
85\end{array}$ & $\begin{array}{l}100 \\
57.1 \\
68.8 \\
6.3 \\
14.3 \\
36.6\end{array}$ & $\begin{array}{l}100 \\
60.1 \\
57.1 \\
11.6 \\
8.9 \\
37.5\end{array}$ \\
\hline
\end{tabular}

Table 7

Low energy CAD MS/MS spectrum of the ammoniated precursor ion $\left[\mathrm{M}+\mathrm{NH}_{4}\right]^{+}$at $\mathrm{m} / \mathrm{z} 321$ of $3^{\prime}$-azido2',3',4'-trideoxy-4'-thio-5-chlorouridine 4.

\begin{tabular}{llcc}
\hline Characteristic ion & Type of ion & $\mathrm{m} / \mathrm{z}$ & $\begin{array}{c}\beta \text {-anomer } \\
(\%)\end{array}$ \\
& Precursor ion & 321 & 100 \\
{$\left[\mathrm{M}+\mathrm{NH}_{4}\right]^{+}$} & {$\left[\mathrm{S}+\mathrm{NH}_{4}\right]^{+}$} & 175 & 11.2 \\
{$\left[\mathrm{M}+\mathrm{NH}_{4}-146\right]^{+}$} & {$\left[\mathrm{BH}_{2}\right]^{+}$} & 147 & 6.3 \\
{$\left[\mathrm{M}+\mathrm{NH}_{4}-175+\mathrm{H}^{+}\right.$} & {$\left[\mathrm{S}+\mathrm{NH}_{4}-\mathrm{HN}_{3}\right]^{+}$} & 132 & 15.1 \\
\hline
\end{tabular}

\section{Table 8}

Positive electrospray mass spectra of 3'-azido-2',3',4'-trideoxy-4'-thio-5-fluorouridine 6 and its corresponding $\alpha$-anomer $7\left(\mathrm{C}_{9} \mathrm{H}_{10} \mathrm{~N}_{5} \mathrm{O}_{3} \mathrm{SF}, \mathrm{M} . \mathrm{W} . \mathrm{t}=287\right)$.

$\begin{array}{lccc}\text { Characteristic ion } & \mathrm{m} / \mathbf{z} & \begin{array}{c}\beta \text {-anomer } \mathbf{6} \\ (\%)\end{array} & \begin{array}{c}\alpha \text {-anomer 7 } \\ (\%)\end{array} \\ {\left[2 \mathrm{M}+\mathrm{NH}_{4}\right]^{+}} & 592 & 35.7 & - \\ {\left[2 \mathrm{M}+\mathrm{H}^{+}\right.} & 575 & 32.1 & 59.3 \\ {\left[\mathrm{M}+\mathrm{NH}_{4}\right]^{+}} & 305 & 100 & 5.4 \\ {[\mathrm{M}+\mathrm{H}]^{+}} & 288 & 94.5 & 100\end{array}$




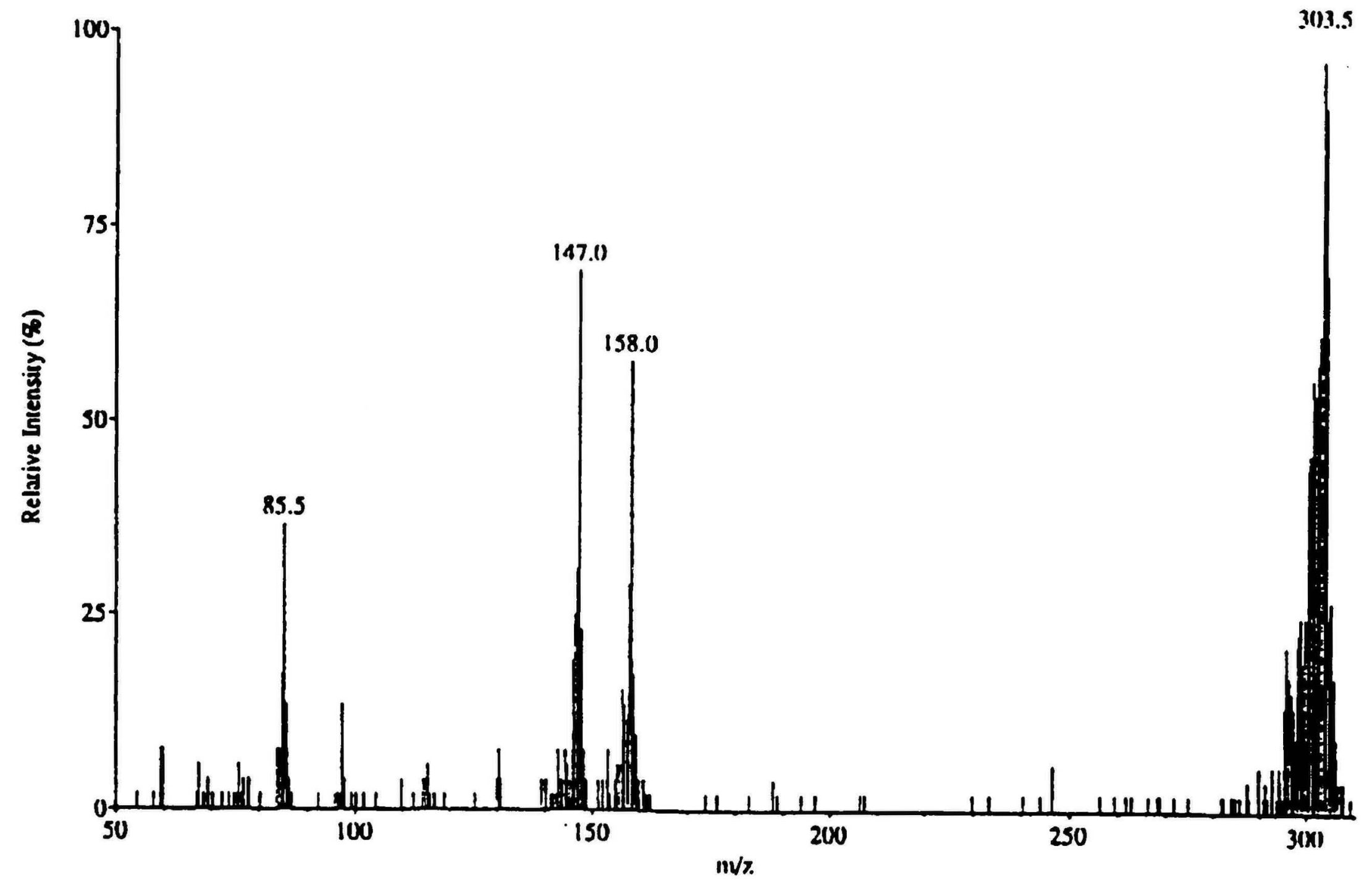

b

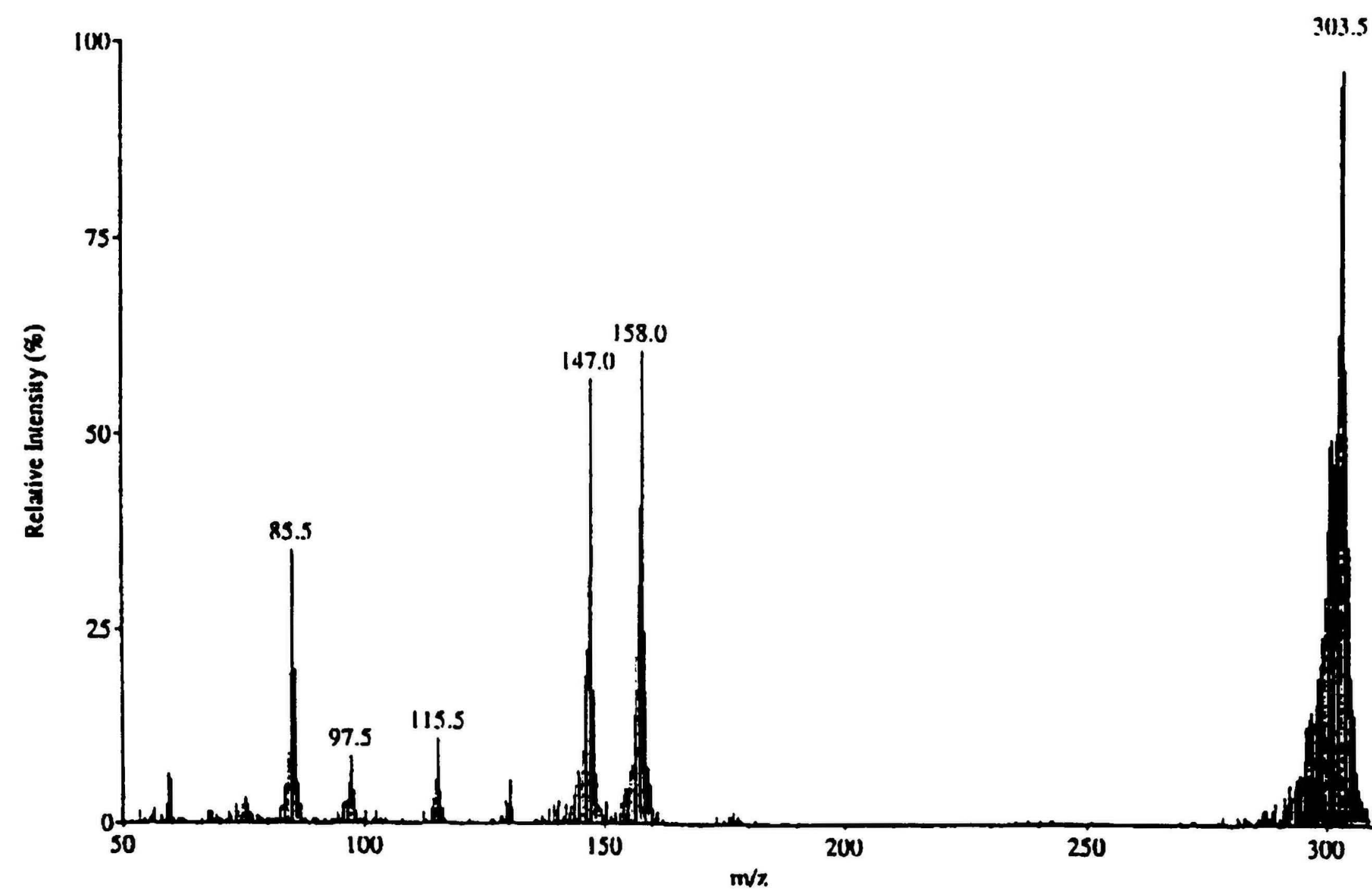

Figure 5. Low energy CAD MS/MS spectra of the precursor ions $[\mathrm{M}+\mathrm{H}]^{+}$at $\mathrm{m} / \mathrm{z} 303.5$ obtained from (a) $3^{\prime}$-azido-2',3',4'-trideoxy-4'-thio-5-chlorouridine 4 and (b) its corresponding $\alpha$-anomer 5. 
Finally, the electrospray mass spectra of the anomeric pair of 3'-azido-2',3',4'-trideoxy-4'thio-5-fluorouridine 6 and 7 were also recorded. The characteristic ions, obtained for this pair of anomers, are presented in Table 8 which shows very distinct spectra. It can be noted that for both anomers the protonated molecules and the $[2 \mathrm{M}+\mathrm{H}]^{+}$cluster ions, at $\mathrm{m} / \mathrm{z}$ 288 and 575 respectively, have different relative abundances. As in the case of 4'-thio-5chlorouridine 4 ( $\beta$-anomer), the $\beta$-anomer 6 also shows the presence of two diagnostic ammoniated adducts, namely the $\left[\mathrm{M}+\mathrm{NH}_{4}\right]^{+}$and $\left[2 \mathrm{M}+\mathrm{NH}_{4}\right]^{+}$ions at $\mathrm{m} / \mathrm{z} 305$ and 592 respectively. The formation of these ions can be rationalized by complexation with an ammonium ion.

The low energy CID MS/MS spectra for the $[\mathrm{M}+\mathrm{H}]^{+}$ions of the anomers 6 and 7 are summarized in Table 9. Examination of this table showed pronounced differences in the intensities of particular fragment-ions, which permitted discrimination between these two anomers. Thus, relative intensities of the product ions $[\mathrm{S}]^{+}$and $\left[\mathrm{S}-\mathrm{HN}_{3}-\mathrm{HCHO}\right]^{+}$ respectively at $\mathrm{m} / \mathrm{z} 158$ and 85 , proved to be of diagnostic value in permitting discrimination between the $\beta$-anomer $\mathbf{6}$ and the corresponding $\alpha$-anomer 7 .

Table 9

Low energy CAD MS/MS spectra of the precursor ions $[\mathrm{M}+\mathrm{H}]^{+}$at $\mathrm{m} / \mathrm{z} 288$ of 3'-azido-2',3',4'-trideoxy-4'thio-5-fluorouridine 6 and its corresponding $\alpha$-anomer 7 .

\begin{tabular}{|c|c|c|c|c|}
\hline Characteristic ion & Type of ion & $\mathrm{m} / \mathrm{z}$ & $\begin{array}{c}\beta \text {-anomer } 6 \\
(\%)\end{array}$ & $\begin{array}{c}\alpha \text {-anomer } 7 \\
(\%)\end{array}$ \\
\hline$[\mathrm{M}+\mathrm{H}]^{+}$ & Precursor ion & 288 & 100 & 100 \\
\hline$[\mathrm{M}+\mathrm{H}-130]^{+}$ & {$[\mathrm{S}]^{+}$} & 158 & 33.9 & 51.8 \\
\hline$\left[\mathrm{M}+\mathrm{H}-158+\mathrm{H}^{+}\right.$ & {$\left[\mathrm{BH}_{2}\right]^{+}$} & 131 & 17.8 & 19.6 \\
\hline$[\mathrm{M}+\mathrm{H}-130-43]^{+}$ & {$\left[\mathrm{S}-\mathrm{HN}_{3}\right]^{+}$} & 115 & 6.3 & 9.8 \\
\hline$[\mathrm{M}+\mathrm{H}-130-43-18]^{+}$ & {$\left[\mathrm{S}-\mathrm{HN}_{3}-\mathrm{H}_{2} \mathrm{O}\right]^{+}$} & 97 & 7.1 & 7.1 \\
\hline$[\mathrm{M}+\mathrm{H}-130-43-30]^{+}$ & {$\left[\mathrm{S}-\mathrm{HN}_{2}-\mathrm{HCHO}\right]$} & 85 & 20.5 & 277 \\
\hline
\end{tabular}

\section{Conclusion}

Mass spectral analyses of AZT 1 and a novel series of 3'-azido-2',3',4'-trideoxy-4'thio-5-(bromo, chloro and fluoro)uridines 2-7 have been effected using electrospray ionization. Abundant signals, corresponding to the protonated molecules and molecular clusters, were observed in all cases using this ionization technique. In addition, the conventional electrospray MS permitted differentiation between the anomeric pairs: (4/5) and $(6 / 7)$. The $\beta$-anomers in both cases formed an ammoniated adduct $\left[\mathrm{M}+\mathrm{NH}_{4}\right]^{+}$.

MS/MS spectra of this novel series of 4'-thio-5-halogenouridines, obtained using low energy collision activation, permitted differentiation between the various anomeric pairs. The difference in the relative abundance of same product ions obtained in the low energy CID MS/MS analyses reflects the inequalities of the chemical free energy, and 
stereochemical differences between the anomeric configurations at C-l' of the 3'-azido2',3',4'-trideoxy-4'-thio-glycososyl moiety, which contribute to the differences in the tertiary structures of the protonated molecular ions generated.

\section{References}

[1] R. C. Gallo, P. S. Sarin, E. P. Gelmann, M. R. Guroff, E. Richardson, V. S. Kalyanaraman, D. Mann, G. D. Sidhic, R. E. Stahl, S. Zoller-Pazner, J. Leibowitch and M. Popovic, Science, 220 (1983) 868.

[2] H. Mitsuya, K. J. Weinhold, P. A. Furman, M. H. St. Clair, S. N. Lehrman, R.C. Gallo, D. Bolognesi, D. W. Barry and S. Broder, Proc. Natl. Acad. Sci.USA, 82 (1985) 7096.

3] (a) H. Mitsuya and S. Broder, Proc. Natl. Acad. Sci. USA, 83 (1986) 1911, and (b) S. Matsuchita, H. Mitsuya, M. S. Reitz and S. Broder, J. Clin. Invest, 80 (1987) 394.

[4] T. S. Lin, J. Y. Guo, R. F. Shinazi, C. K. Chu, J. N. Xiang, W. H. Pursoff, J.Med. Chem., 31 (1988) 336.

[5] J. A. Montgomery, Studies on the biological activity of Purine and pyrimidine Analogs, Med. Res. Rev., 2 (1982) 271-308.

[6] R. E. Parks Jr., J. D. Stoekler, C. Cambor, T. M. Savarese, G. W. Crabtree, S. H. Chu. Purine nucleoside phosphorylase and 5'-methylthioadenosinephosphorylase: Targets of Chemotherapy. Molecular Actions and Targets for Cancer Chemotherapeutic Agents. (A. C. (Sartorelli, J. S. Lazo, J. R. Bertino, Eds), pp. 229-252, Academic press: New York (1981).

[7] M. R. Dyson, P. L. Coe and R. T. Walker, J. Med. Chem., 34 (1991) 2782-2786.

[8] J. A. Secrist III, R. Riggs, K. Tiwari and J. A. Montgomery, J. Med. Chem., 35 (1991) 533-538.

[9] B. Tber, N. Fahmi, G. Ronco, G. Mackenzie, D. Ewing and P. Villa, Nucleosides \& Nucleotides, submitted for publication.

[10] C. M. Whitehouse, R. N. Dreyer, M. Yamashita and J. B. Fenn, Anal. Chem., 57 (1985) 675.

[11] C. K. Meng, M. Mann and J. B. Fenn, Z. Phys. D., 10 (1988) 361.

[12] J. A. Loo, Rapid Comm Mass Spectrom, 5 (1991) 101.

[13] B. Ganem, Y. T. Li and J. D. Henion, J. Am. Chem.Soc., 113 (1991) 6294.

[14] B. Ganem, Y. T. Li and J. D. Henion, J. Am. Chem. Soc., 113 (1991) 7818.

[15] M. Bacan and S. B. H. Kent, J. Am. Chem. Soc., 114 (1992) 3992.

[16] R. T. Alpin, J. E. Baldwin, C. J. Shofield and S. G. Waley, FEBS Lett., 277 (1990) 212.

[17] D. S. Ashton, C. R. Bedell, P. J. Cooper, B. N. Green, R. W. A. Oliver and K. J. Welham, FEBS Lett., 292 (1991) 201.

[18] R.Menard, R. Feng, A. C. Storer, V. G. Robinson, R. A. Smith and A. Krantz, FEBS Lett., 295 (1991) 27.

[19] C. Chauvin, P. Thibault, D. Plusquellec and J. Banoub, J. Carbohydr. Chem, 12 (1993) 459-475.

[20] F. W. Crow, K. B. Tomer, M. L. Gross, J. A. Mc Closkey and D. E. Bergstrom, Anal. Biochem., 139 (1984) 243.

[21] P. F. Crain, Mass Spectrom. Rev., 9 (1990) 505.

[22] Z. Zhou, S. Ogden, J. A. Leary, J. Org. Chem., 55 (1990) 5444.

[23] R. A. Laine, K. M. Pamidimukkala, A. D. French, R. W. Hall, S. A. Abbas, R. K. Jain and K. L. Matta, J. Am. Chem. Soc., 110 (1988) 6931.

[24] J. W. Dallinga, W. Heerma, Biol. Mass Spectrom, 20 (1991) 99.

[25] B. Domon, J. E. Vath, C. E. Costello, Anal. Biochem., 184 (1990) 151.

[26] W. J. Richter, W. Blum, U. P. Schlunegger and M. Senn in Tandem Mass Spectrometry, F. W. Mclafferty, Ed, Wiley: New York, 1983, p. 417.

[27] R. Guevremont and J. L. C. Wright, Rapid Comm Mass Spectrom., 1 (1987) 12.

[28] D. R. Mueller, B. M. Domon, W. Blum, F. Raschdorf and W. J. Richter, Biomed. Env. Mass Spectrom, 15 (1988) 441.

[29] A. Ballistreri, G. Montaudo, D. Garozzo, M. Giuffrida and G. Impallomeni, Rapid Comm Mass Spectrom, 3 (1989) 302.

[30] B. Domon, D. R. Muller and W. J. Richter, Org. Mass Spectrom, 24 (1990) 101.

[31] R. Guevremont V. P. Pathak and J. L. C. Wright, Org. Mass Spectrom., 25 (1990) 101.

[32] G. Puzo, J. C. Prome and J. J. Fournier, Carbohydr. Res., 140 (1985) 131.

[33] T. R. Covey, R. F. Bonner, B. 1. Shushan and J. Heniou, Rapid Comm. Mass Spectrom, 249 (1988).

[34] F. W. Mclafferty, Tandem Mass Spectrometry, Ed, Wiley-Interscience: New York, 1983.

[35] Mass Spectrometry, K. L. Bush, G. L. Glish and S. A. Mc Luckey, Eds; VCH: New York, 1988. 
[36] R. Helleur, P. Thibault, J. Banoub and D. H. Shaw, Org. Mass Spectrom, 27 (1992) 967-973.

[37] J. Banoub, G. MacKenzie, G. Descotes, R. W. Humble, G. Shaw, M. Becchi and D. Fraisse, Biomed. Environ. Mass Spectrom, 19 (1990) 97.

[38] J. Banoub, M. Becchi, G. Descotes, D. Fraisse, R. W. Humble and G. MacKenzie, Spectroscopy, 9 (1991) 79.

[39] J. Banoub, M. Becchi, G. Descotes, D. Fraisse, R. W. Humble and G.MacKenzie, J. Carbohydr. Chem, 11 (1992) 417.

[40] M. Brakta, P. Lhoste, D. Sinou and J. Banoub, Carbohydr. Res., 203 (1990) 148.

[41] M. Brakta, P. Lhoste, D. Sinou, M. Becchi, D. Fraisse and J. Banoub, Org. Mass Spectrom, 25 (1990) 249.

[42] M. Brakta, B. Shagir, D. Sinou, J. Banoub and M. Becchi, Org. Mass Spectrom., 27 (1992) 249.

[43] M. Brakta, D. Sinou, M. Becchi and J. Banoub, Org. Mass Spectrom., 27 (1992) 621.

[44] J. Banoub, M. Becchi, D. Lafont, D. Fraisse and G. Descotes, Rapid Comm. Mass Spectrom., 4 (1990) 536.

[45] J. Banoub, D. Lafont, M. Becchi, D. Fraisse and G. Descotes, Spectroscopy, 10 (1992) 71. 


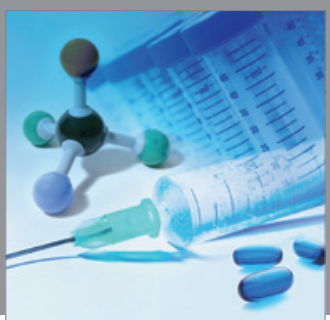

International Journal of

Medicinal Chemistry

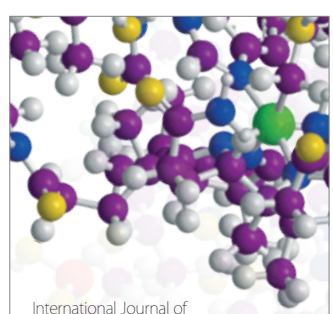

Carbohydrate Chemistry

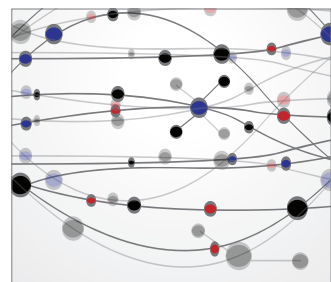

The Scientific World Journal
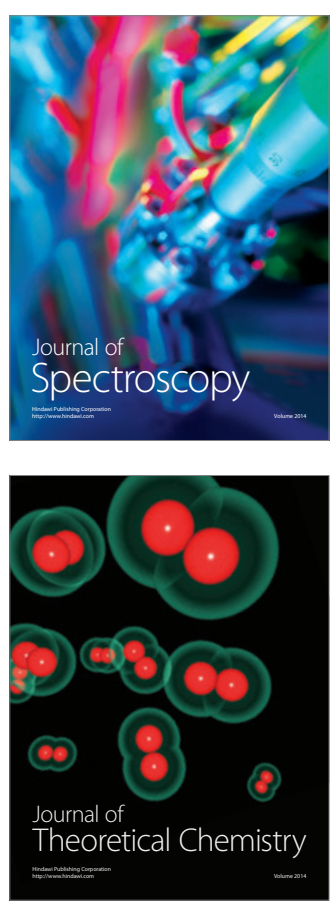
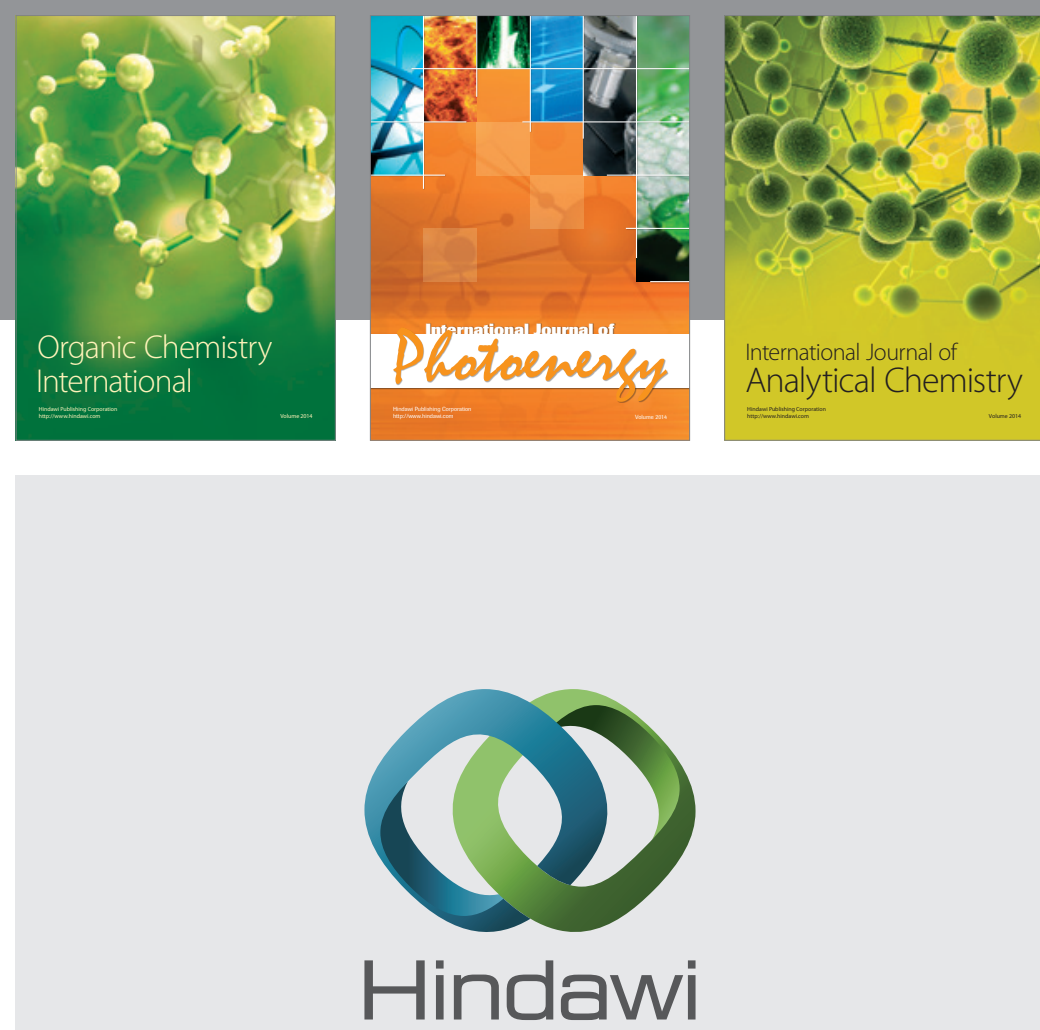

Submit your manuscripts at

http://www.hindawi.com
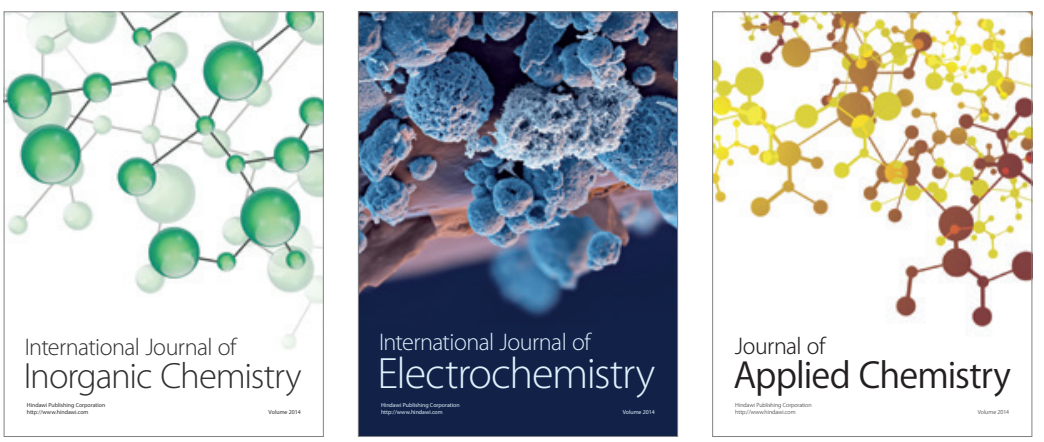

Journal of

Applied Chemistry
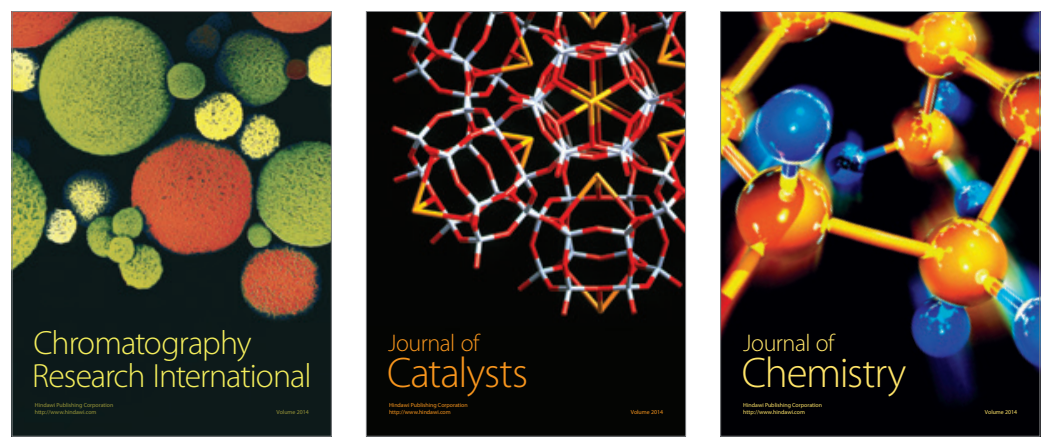
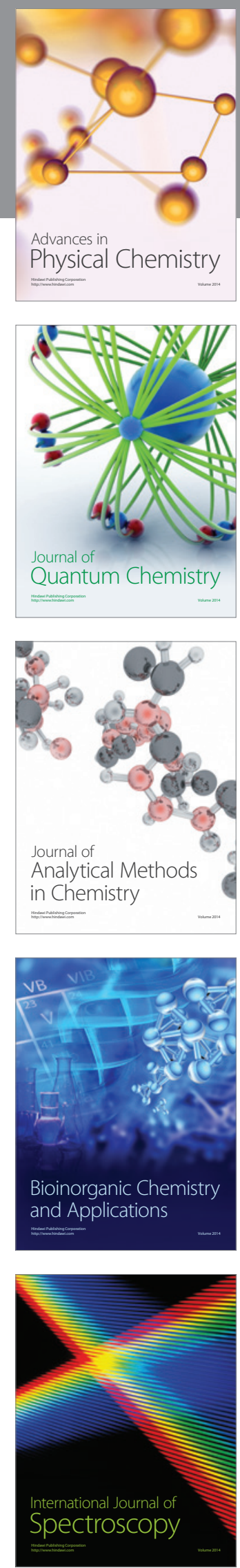